\title{
Trace Metal Metabolism in Cultured Skin Fibroblasts of the Mottled Mouse: Response to Metallothionein Inducers
}

\author{
SEYMOUR PACKMAN AND CYNTHIA O'TOOLE \\ Division of Genetics, Department of Pediatrics, University of California, San Francisco, California 94143
}

\begin{abstract}
Menkes' kinky hair syndrome is a lethal Xlinked disorder marked by tissue-specific increases in copper content. An animal model of kinky hair syndrome is provided by mice mutant at the $\mathrm{X}$-linked mottled locus. The basic defect is unknown. In order to discriminate among potential etiologies, we asked whether the expression of the mottled mutation causes abnormalities in the metabolism of trace metals other than copper in hemizygous mottled (blotchy) cultured skin fibroblasts, and whether we can differentiate mutant and normal cells according to their response to metal inducers of metallothionein. Blotchy fibroblasts accumulated up to 12 times more ${ }^{64} \mathrm{Cu}$ than control (littermate) cells, over time and over a range of ${ }^{64} \mathrm{Cu}$ concentrations. A saturable high affinity component to ${ }^{64} \mathrm{Cu}$ accumulation over a fixed time interval was revealed in these studies. While ${ }^{64} \mathrm{Cu}$ uptake kinetics were indistinguishable in mutant and control cells, the patterns of ${ }^{64} \mathrm{Cu}$ exit differed. In both cell types, the rate of release of a rapidly exchangeable fraction of newly acquired ${ }^{64} \mathrm{Cu}$ was similar. However, in mutant cells, a larger fraction of recently accumulated ${ }^{64} \mathrm{Cu}$ is retained. In contrast to the results for ${ }^{64} \mathrm{Cu}$, accumulation and exit of ${ }^{65} \mathrm{Zn}$ and ${ }^{109} \mathrm{Cd}$ were not distinguishable in mutants and controls. With exposure to either a strong (cadmium) or weaker (zinc) inducer of metallothionein, ${ }^{64} \mathrm{Cu}$ accumulation was increased in normal cells, while there was no change from the already elevated level of ${ }^{64} \mathrm{Cu}$ accumulation in blotchy cells. In contrast, the effects of metal inducers of metallothionein on ${ }^{65} \mathrm{Zn}$ or ${ }^{109} \mathrm{Cd}$ accumulation in mutant cells were indistinguishable from the effects on controls. The present observations reveal that blotchy fibroblasts exhibit normal accumulation and exit of metals other than copper, and evince a differential response to metallothionein inducers, which response is also limited to the accumulation of copper. When considered together with the larger body of data on the kinky hair syndrome and mottled mutation, we infer that the defect in both species resides in the function of a thionein or other protein specifically binding copper; or in an altered transport system specifically affecting copper. (Pediatr Res 18:1282-1286, 1984)
\end{abstract}

Received February 13, 1984; accepted May 25, 1984.

Correspondence may be addressed to Dr. Seymour Packman, Division of Genetics, Department of Pediatrics, University of California, San Francisco, CA 94143.

This work was supported by National Institutes of Health Grant GM 28838. Portions of this work were presented to the annual meeting of the Society for Pediatric Research, 1982, and published in abstract form in Pediatr Res 16:194A, 1982.
Menkes' kinky hair syndrome is an X-linked recessive disorder with decreased serum copper and ceruloplasmin-copper oxidase, and relative copper deficiency in many organs in the face of tissue-specific copper sequestration. Clinical features include pili torti, hypopigmentation, seizures, hypothermia, growth failure, skeletal defects, arterial aneurysms, and progressive degeneration of the central nervous system. The disease terminates fatally by age 3 years, with prominent postmortem findings including gliosis, neuronal degeneration, and defects of the arterial intima (8).

An animal model of Menkes' kinky hair syndrome is provided by mice mutant at the X-linked mottled locus $(11,21)$. Mice hemizygous for the brindled and the blotchy alleles at the mottled locus have been extensively studied. Striking correspondences in distinctive clinical, pathologic, and chemical features $(3,11,21$, $27,35)$ suggest that the human and murine $X$-linked recessive diseases represent defects at a locus serving the same function in both species. The X-linkage itself is strongly supportive of identity, since X-linked loci are highly conserved through evolution (28).

The precise nature of the defect has remained obscure. The recent assignment of mouse (7) and human (17) metallothionein genes to autosomes mitigates strongly against a primary structural defect in that class of proteins. However, hypotneses which emphasize defects in the modulation of metallothionein function, in the quantitative regulation of metallothioneins, or in transport of metals must still be addressed. In order to derive information of value in discriminating among possible etiologies, we ask in the present studies whether the expression of the mottled (blotchy, $\mathrm{Mo}^{\mathrm{blo}}$ ) mutation in mice causes abnormalities in the metabolism of trace metals other than copper, and whether we can differentiate mutant and normal cells according to their responses to metal inducers of metallothionein.

\section{MATERIALS AND METHODS}

Isotopes. The $\gamma$ emitters, ${ }^{64} \mathrm{Cu}\left(t_{1 / 2}=12.8 \mathrm{~h}\right),{ }^{109} \mathrm{Cd}\left(t_{1 / 2}=450\right.$ days), and ${ }^{65} \mathrm{Zn}\left(t_{1 / 2}=244\right.$ days), were purchased from New England Nuclear Corporation. The ${ }^{64} \mathrm{Cu}\left(\mathrm{NO}_{3}\right)_{2}$ was delivered at a specific activity of approximately $4 \mathrm{mCi} / \mathrm{mg}$ of copper at time of receipt. The ${ }^{109} \mathrm{Cd}$ and ${ }^{65} \mathrm{Zn}$ were purchased carrier free, and diluted with nonradioactive salts as needed for specific experiments.

Mutants. Experiments were carried out on cultured skin fibroblasts of mice hemizygous for the blotchy mutant allele at the mottled locus $\left(\mathrm{Mo}^{\mathrm{blo}} / \mathrm{y}\right)$, and on cells similarly derived from normal male littermates. Mutant and control mice were obtained as offspring of heterozygous females $\left(\mathrm{Mo}^{\text {blo }} /+\right)$ and normal males, both of strain $\mathrm{C} 57 \mathrm{BL} / 6 \mathrm{~J}$ and purchased as breeding pairs 
from Jackson Memorial Laboratory. Animals were housed in a room set aside for mutant mice in the Animal Care Facility, University of California, San Francisco.

Cell propagation. Fibroblasts were grown in Dulbecco's modified Eagle's Medium-H21 medium (4.5 g glucose/liter), plus fetal calf serum to $10 \%$ and added penicillin and streptomycin ( 100 units $/ 10 \mathrm{ml}$ and $100 \mu \mathrm{g} / 10 \mathrm{ml}$, respectively) in the complete medium. To propagate cells for specific experiments, confluent cultures were harvested with $0.15 \%$ Pronase, rinsed and pelleted in Hanks'-CMF $\left(\mathrm{Ca}^{++}, \mathrm{Mg}^{++}\right.$free) solution, resuspended in complete medium, plated onto tissue culture dishes as a 1:2 split, and regrown to confluent density. The copper concentration in baseline complete medium was $0.76 \mu \mathrm{M}$, as determined by atomic absorption spectrophotometry (31).

Isotope accumulation studies. With cells in culture dishes at confluent density, isotope was added immediately after a change of medium, at concentrations and for times as indicated. Following incubations, cells were washed free of radioactivity, harvested with a rubber policeman into phosphate-buffered saline $\left(\mathrm{Ca}^{2+}\right.$, $\mathrm{Mg}^{2+}$ free, $\mathrm{pH} 7$ or 7.4), and dissolved by heating for $2 \mathrm{~h}$ at $45^{\circ}$ $\mathrm{C}$ in $0.75 \mathrm{~N} \mathrm{NaOH}$. Aliquots were counted in a $\gamma$ scintillation counter peaked for the appropriate isotope (30), and protein was determined in a duplicate aliquot by standard procedures (26). ${ }^{64} \mathrm{Cu}$ counts were corrected for decay, as described (30).

\section{RESULTS}

Copper sequestration.is a chemical hallmark of disease expression in mouse and human mutant tissues, and this phenotypic parameter was documented in the blotchy fibroblasts used for our studies. In addition, in order to address questions of mechanism, the kinetics of accumulation were examined in detail (Figs. 1-4). When cultured skin fibroblasts from normal male and hemizygous blotchy mice were exposed for varying times to $3.1 \mu \mathrm{M}$ copper as ${ }^{64} \mathrm{Cu}$, there was a striking 4 - to 12 -fold difference in ${ }^{64} \mathrm{Cu}$ accumulation in normal as compared with mutant cells (Fig. 1). Whereas control cells reached an equilibrium in ${ }^{64} \mathrm{Cu}$ content within $10-24 \mathrm{~h}$, there was a continuing increase in ${ }^{64} \mathrm{Cu}$ accumulation in blotchy cells.

With incubation for a fixed time interval $(18 \mathrm{~h})$ over a range of ${ }^{64} \mathrm{Cu}$ concentrations up to $32 \mu \mathrm{M}$ (Fig. 2), accumulation of isotope in mutant cells rapidly reached a maximal level at incubation medium ${ }^{64} \mathrm{Cu}$ concentrations of $1.6-7.9 \mu \mathrm{M}$. At those concentrations of ${ }^{64} \mathrm{Cu}$, accumulation in blotchy cells was 6- to 13-fold greater than in control fibroblasts. With exposure to higher concentrations of medium ${ }^{64} \mathrm{Cu}$ over this same fixed time interval, more ${ }^{64} \mathrm{Cu}$ accumulated in control fibroblasts, and the difference between mutant and normal ${ }^{64} \mathrm{Cu}$ content decreased. These relative changes were similarly and recently recognized in kinky hair syndrome lymphoblasts (34).

To approximate and assess actual uptake of copper, ${ }^{64} \mathrm{Cu}$ accumulation was measured in cells at very early time intervals $(0.5$ to $15 \mathrm{~min})$ following addition of isotope (Fig. 3). This experiment was performed at a copper concentration previously shown to result in maximal differences between mutant and normal radiocopper accumulation ( $c f$. Fig. 2). Over this time interval, the slopes of the regression lines for the normal and mutant data points were not distinguishable when subject to a one-tailed $(p>0.05)$ or two-tailed $(p>0.10)$ test using the $t$ statistic (12) (Fig. 3).

In contrast, the kinetics of copper exit differ in blotchy and control cells. Following loading with isotope, ${ }^{64} \mathrm{Cu}$ release was assessed as ${ }^{64} \mathrm{Cu}$ content retained in paired mutant and normal cultures at serial time points after removal of isotope and supplemental copper salts from the medium (Fig. 4). In both mutant and normal cells loaded with ${ }^{64} \mathrm{Cu}$, there is a fraction of that newly acquired intracellular ${ }^{64} \mathrm{Cu}$ which is rapidly released over the first $2-3 \mathrm{~h}$ after loading. The rate of release of this exchangeable fraction is not distinguishable in the two cell types. Rather, the major difference between mutant and control cells resides in the relative magnitude of the retained and exchangeable frac-

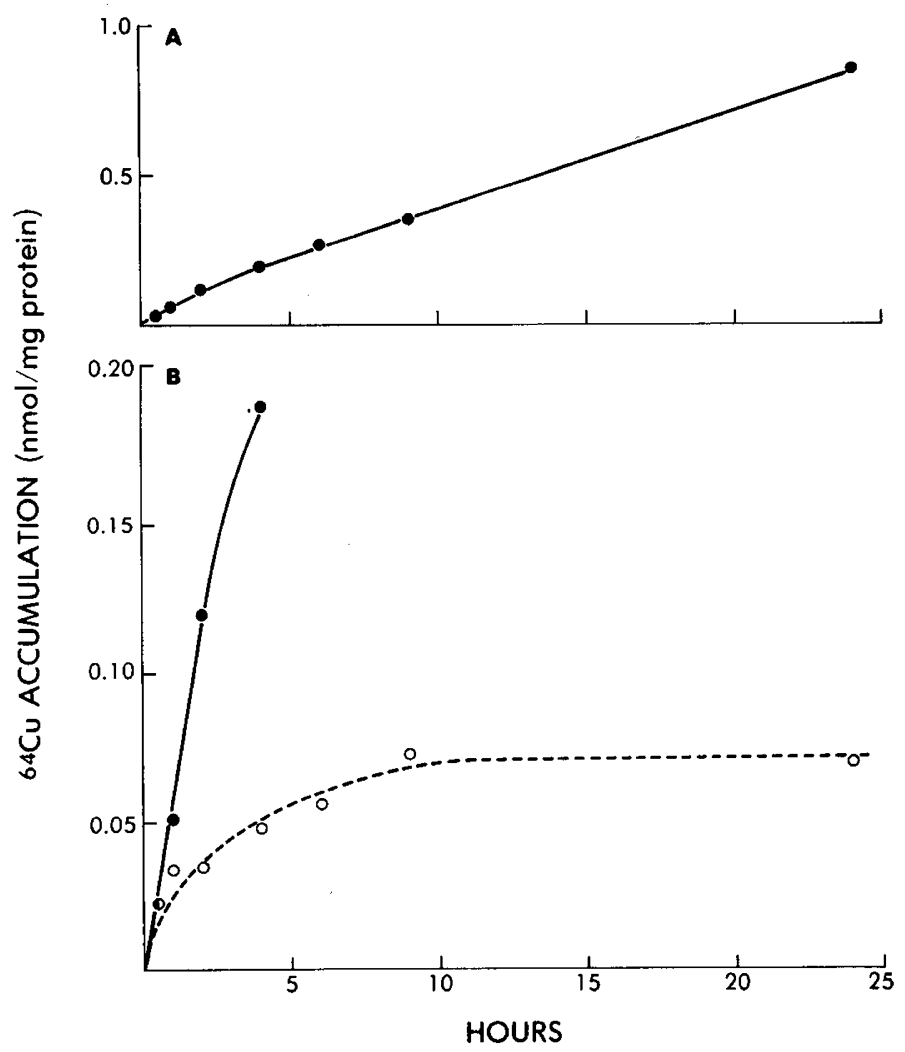

Fig. $1 .{ }^{64} \mathrm{Cu}$ accumulation in whole fibroblasts over time. Cells were propagated and prepared for study as in "Materials and Methods." Incubations were in $3.1 \mu \mathrm{M}{ }^{64} \mathrm{Cu}$ as ${ }^{64} \mathrm{Cu}\left(\mathrm{NO}_{3}\right)_{2}$ for the times indicated. Each data point represents a single determination in a representative experiment pairing mutant $(\bullet)$ and control $(O)$ cultures. ${ }^{64} \mathrm{Cu}$ accumulation is expressed as $\mathrm{nmol}{ }^{64} \mathrm{Cu} / \mathrm{mg}$ cell protein. Panels $A$ and $B$ represent the same experiment, with the expanded scale in $B$ presented to permit more direct comparison of control versus mutant radiocopper accumulation. These and subsequent experiments were performed on cells ranging in passage number from $8-25$; no variation in ${ }^{64} \mathrm{Cu}$ accumulation was found with passage number or extent of spontaneous transformation of the mouse fibroblasts.

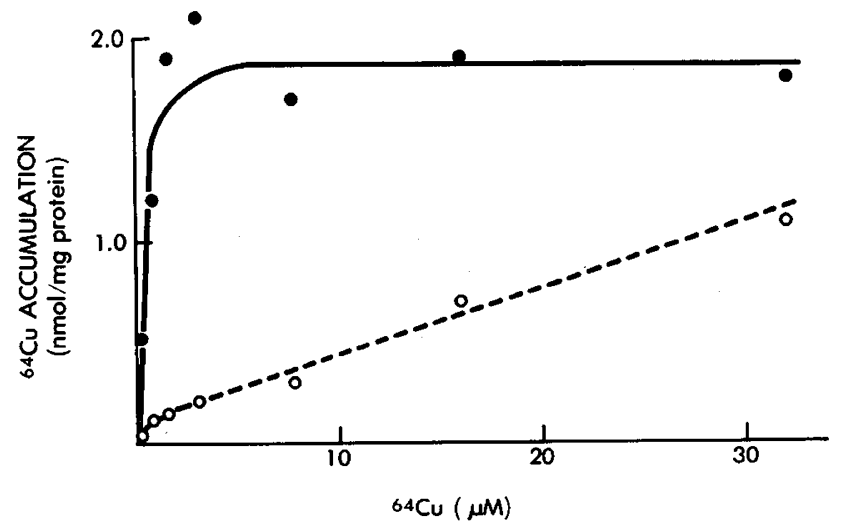

Fig. 2. ${ }^{64} \mathrm{Cu}$ accumulation in whole fibroblasts over a range of copper concentrations. Cells were propagated and prepared for study as in "Materials and Methods." Incubation was for $18 \mathrm{~h}$ at the indicated ${ }^{64} \mathrm{Cu}$ concentrations $\left[\mathrm{as}^{64} \mathrm{Cu}\left(\mathrm{NO}_{3}\right)_{2}\right.$ ], with each data point representing a single determination in a representative experiment pairing mutant $(\bullet)$ and control $(O)$ cultures. ${ }^{64} \mathrm{Cu}$ accumulation is expressed as $\mathrm{nmol}{ }^{64} \mathrm{Cu} / \mathrm{mg}$ cell protein.

tions. In mutant cells, a large fraction of recently accumulated ${ }^{64} \mathrm{Cu}$ is not released under these conditions. The above observations are supported by and serve to extend reports in a number of mutant cell types $(1,4,20,33)$. 


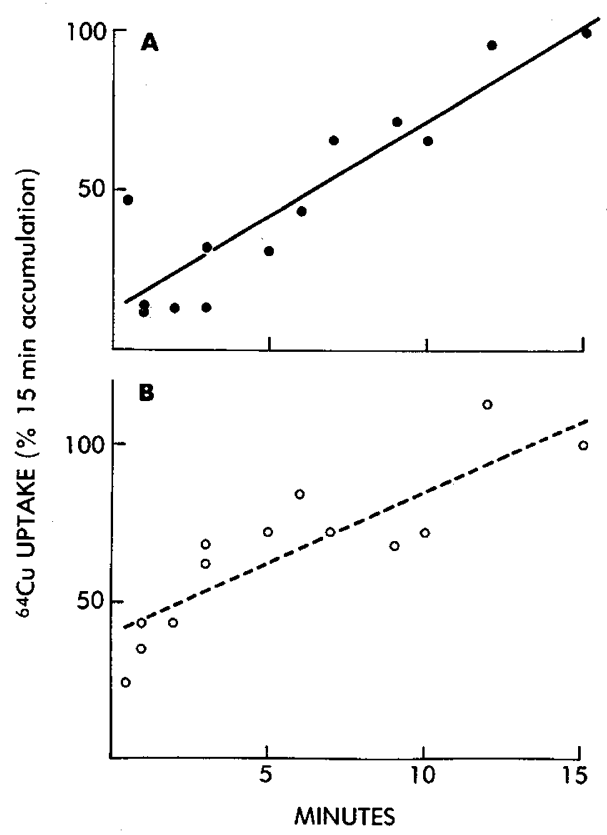

Fig. $3 .{ }^{64} \mathrm{Cu}$ uptake in whole fibroblasts. Cells were propagated and prepared for study as in "Materials and Methods." Incubations were in $3.1 \mu \mathrm{M}{ }^{64} \mathrm{Cu}$ as ${ }^{64} \mathrm{Cu}\left(\mathrm{NO}_{3}\right)_{2}$ for the times indicated. Each data point represents a single determination; depicted on the graph are all data points of two separate experiments, with each experiment pairing mutant $(\bullet)$ and control $(O)$ cells. Regression lines for mutant (solid line, panel $A$ ) and control (broken line, panel $B$ ) results are drawn as described in the text. The ${ }^{64} \mathrm{Cu}$ uptake was calculated as in the accumulation studies $\left(\mathrm{nmol}{ }^{64} \mathrm{Cu} / \mathrm{mg}\right.$ cell protein; $c f$. Figs. 1 and 2$)$, but is here expressed as a percentage of the 15-min accumulation value. That 15-min accumulation value was similar in mutant and control in each of the two paired experiments.

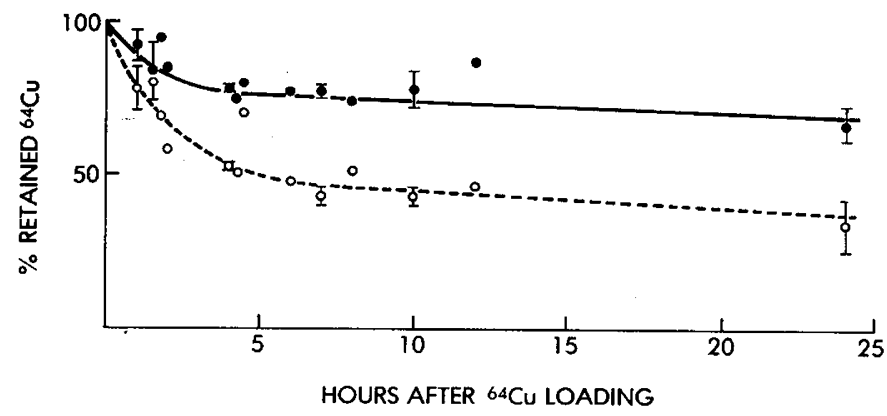

Fig. $4 .{ }^{64} \mathrm{Cu}$ exit. Cells were propagated, prepared for experiment, and incubated (loaded) for $16-18 \mathrm{~h}$ in $3.1 \mu \mathrm{M}{ }^{64} \mathrm{Cu}$ as ${ }^{64} \mathrm{Cu}\left(\mathrm{NO}_{3}\right)_{2}$, as described in the legend for Figure 2 . At $18 \mathrm{~h}$, the medium was changed to baseline medium, as described in "Materials and Methods," and ${ }^{64} \mathrm{Cu}$ content as $n$ mol ${ }^{64} \mathrm{Cu} / \mathrm{mg}$ cell protein was measured after subsequent time intervals as indicated. The results are expressed as a percentage of the copper content at zero time after loading, i.e. immediately after removal of medium containing ${ }^{64} \mathrm{Cu}\left(\mathrm{NO}_{3}\right)_{2}$. The results of four separate experiments, each pairing a mutant $(\Theta)$ and control $(O)$ are depicted on the graph. The data points represent either a single determination at a time postloading, or the mean \pm SE derived from 2-4 independent determinations at a given time postloading.

Importantly, and in striking contrast to the abnormal copper exit and accumulation in mutant cells, accumulation of related trace metals is normal in the blotchy fibroblasts. Incubation of cells in ${ }^{65} \mathrm{Zn}$ resulted in identical patterns of accumulation of isotope over time (Fig. 5) and over a range of concentrations (data not shown) in both cell types. Analogously, ${ }^{109} \mathrm{Cd}$ accumulation was virtually identical in both cell types when measured over time (Fig. 6) or over a range of ${ }^{109} \mathrm{Cd}$ concentrations (data

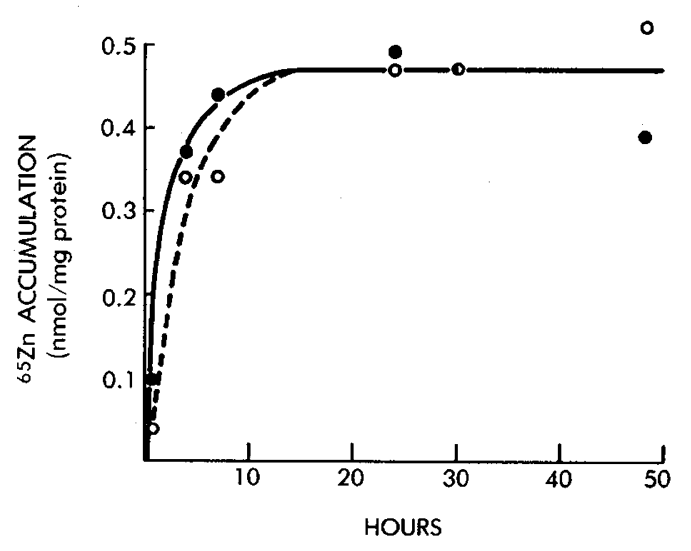

Fig. $5 .{ }^{65} \mathrm{Zn}$ accumulation in whole fibroblasts over time. Experimental procedures are as in the legend for Figure 1, with mutant (O) and control (O) cells incubated in $3.1 \mu \mathrm{M} \mathrm{Zn}$ as ${ }^{65} \mathrm{ZnCl}_{2}$ for the times indicated. Accumulation was measured as $\mathrm{nmol}{ }^{65} \mathrm{Zn} / \mathrm{mg}$ cell protein.

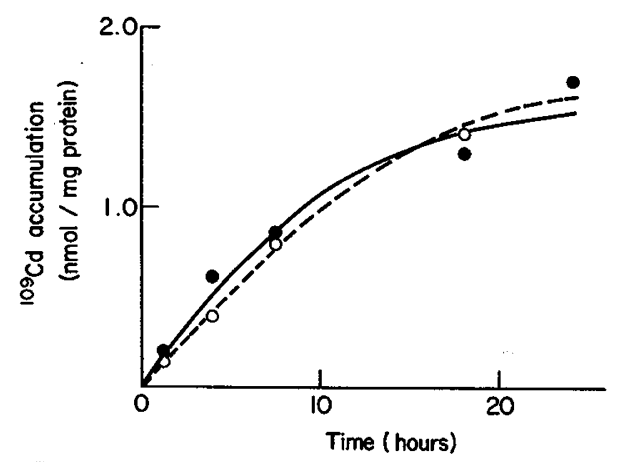

Fig. $6 .{ }^{109} \mathrm{Cd}$ accumulation in whole fibroblasts over time. Experimental procedures are as in the legends for Figures 1 and 5, with mutant (O) and control (O) cells incubated in $1.8 \mu \mathrm{M}{ }^{109} \mathrm{Cd}$ as ${ }^{109} \mathrm{CdCl}_{2}$ for the times indicated. Accumulation was measured as $\mathrm{nmol}{ }^{109} \mathrm{Cd} / \mathrm{mg}$ cell protein.

not shown). These data are consonant with the results of studies in kinky hair syndrome lymphoblasts (34), over the range of metal concentrations used herein. However, at extremely elevated concentrations of zinc and cadmium, differences were observed between normal and mutant cells in the lymphoblast work (34). We speculate that such differences might be related to the toxicity of extreme concentrations of zinc and cadmium on mutant versus normal cells (4).

Again in contrast to the results for copper, the kinetics of release of newly accumulated ${ }^{65} \mathrm{Zn}$ and ${ }^{109} \mathrm{Cd}$ were comparable in control and blotchy cells. For each metal, the patterns of release and the magnitude of the retained fractions were quite similar in the two cell types (data not shown).

As a first approximation and based on the above results, the defect in the blotchy mutation appears to specifically affect copper storage or transport, with the metabolism of zinc and cadmium unaffected. Such specificity is additionally reflected in the differential responses of blotchy and littermate cells to metal inducers of metallothionein. If fibroblast ${ }^{64} \mathrm{Cu}$ accumulation is measured following exposure to cadmium over an 18-h incubation period (Table 1), control cells accumulate $2 \frac{1 / 2}{2}$ to $4 \frac{1}{2}$ times more ${ }^{64} \mathrm{Cu}$ than cells not exposed to cadmium. In contrast, in blotchy cells, ${ }^{64} \mathrm{Cu}$ accumulation does not appreciably change from an already elevated level. These differences obtain over a 20 -fold range of medium copper concentrations (Table 1).

A similar differential response between normal and blotchy cells is observed when ${ }^{64} \mathrm{Cu}$ accumulation is measured during exposure to zinc, a weaker inducer of metallothionein than is cadmium. Normal cells respond to increased zinc concentrations with corresponding increments in ${ }^{64} \mathrm{Cu}$ accumulation, while there 
Table 1. Effect of cadmium on copper accumulation

\begin{tabular}{|c|c|c|c|}
\hline & \multirow[b]{2}{*}{$\mathrm{Cu}(\mu \mathrm{M})$} & \multicolumn{2}{|c|}{$\begin{array}{l}{ }^{64} \mathrm{Cu} \text { accumulation } \\
\text { (nmol/mg protein) }\end{array}$} \\
\hline & & $-\mathrm{Cd}$ & $+\mathrm{Cd}(1.8 \mu \mathrm{M})$ \\
\hline \multirow[t]{3}{*}{ Normal } & 0.16 & 0.067 & 0.21 \\
\hline & 0.79 & 0.077 & 0.34 \\
\hline & 3.1 & 0.17 & 0.41 \\
\hline \multirow[t]{3}{*}{ Blotchy } & 0.16 & 0.41 & 0.49 \\
\hline & 0.79 & 1.3 & 1.2 \\
\hline & 3.1 & 1.6 & 1.9 \\
\hline
\end{tabular}

is no change in ${ }^{64} \mathrm{Cu}$ accumulation in mutant cells under these conditions (data not shown). These results differ in part from measurements reported in kinky hair syndrome lymphoblasts in a related, but not identical, experiment (34).

Such differential responses to metal inducers of metallothionein are, significantly, limited to the handling of copper. Exposure to cadmium does not change ${ }^{65} \mathrm{Zn}$ accumulation in either normal or mutant cells; and in the reverse of a previous experiment, the kinetics of ${ }^{109} \mathrm{Cd}$ accumulation are identical in mutant and control cells with incubation of cells in up to $472 \mu \mathrm{M} \mathrm{Cu}$ (data not shown).

\section{DISCUSSION}

It was recognized early that certain of the phenotypic manifestations of X-linked Menkes' kinky hair syndrome and the mottled mouse could be attributed to relative copper deficiency and consequent reduced activity of a number of cuproenzymes $(8,9$, $18,21)$. Documentation of defective gastrointestinal absorption lent support to such a pathophysiologic sequence (9). The seminal studies of Danks and co-workers developed the important and broader construct that the defective gastrointestinal absorption in kinky hair syndrome was, in fact, only one manifestation of a tissue-specific copper sequestration defect (10), a concept since confirmed in multiple studies of whole tissues and cultured cells $(1,3,4,6,14-16,19-22,27,29,30,32-35)$.

Metallothioneins have been identified as the major intracellular metal-binding protein in a variety of normal (23) and mutant $(2,5,6,24,25,32,34)$ tissues. An excessive accumulation of cadmium in kinky hair syndrome fibroblasts was invoked to support the postulate of a mutant metallothionein in this disorder (6), and additional work in those cells (6) suggested the existence of structurally abnormal metallothioneins with decreased affinity for copper. In contrast, data from other workers supported the contention that kinky hair syndrome metallothioneins displayed normal affinities for copper (24).

With the demonstration of autosomal localization of individual metallothionein genes in mouse (7) and man (17), it became unlikely that a metallothionein would be implicated as the primary gene product of the Menkes' kinky hair syndrome or the mottled locus. Most importantly, the reports of increased intracellular levels of normally functioning metallothionein (2, $25)$ strengthened the possibility of a regulatory defect in metallothionein synthesis in these disorders (34), to be considered additionally with hypotheses focusing on modulations of metallothionein function (30) or transport defects independent of metallothionein function $(2,31)$.

Studies in the mottled mouse have served to confirm and extend the phenotype of kinky hair syndrome $(3,4,11,14,21$, $22,27,30-33,35)$. Our present studies in blotchy cultured skin fibroblasts were designed to ask whether the expression of the blotchy mutation causes abnormalities in the metabolism of trace metals other than copper at the cellular level, and to ascertain whether we can differentiate mutant and normal cells according to their response to metallothionein inducers. Underlying the experiments was the intent to derive information of value in discriminating among potential etiologies of the mottled and, by extension, the kinky hair syndrome phenotype.

The blotchy fibroblasts used in the present studies expressed the copper sequestration phenotype variously described in kinky hair syndrome cultured cells $(1,6,15,16,20,29,34)$, in brindled cells $(4,33)$, and in a study of copper content in blotchy fibroblasts (35). It is of interest that, at the range of copper concentrations tested, there appeared to be a saturable component to radiocopper accumulation over a fixed time intervai. A similar saturable high affinity component was observed in kinky hair syndrome lymphoblasts (34).

Previous studies focusing on a measure of actual uptake of copper into mutant cells have been approximate (4) or have yielded equivocal results (16). Accordingly, the clear demonstration herein of normal copper uptake in blotchy cells provides a firm and reasonable basis for focusing on the mechanisms of copper exit in these and related mutants.

The kinetics of copper exit were quite different in mutant and normal cells. In both cell types, there appeared to be more than one component of radiocopper release immediately following loading with isotope. The rate of exit of a rapidly exchangeable fraction was not clearly distinguishable in blotchy and controls. However, the magnitude of the exchangeable fraction-or, conversely, of the retained fraction-was quite different, with mutant cells retaining an excessive percentage of recently acquired radiocopper. Our conclusions are supported by data presented in a somewhat different form in studies of kinky hair syndrome (1, $20)$ and brindled $(4,33)$ cells.

In contrast to the increased sequestration of copper in mutant cells, zinc and cadmium accumulation and exit are not altered. At the broad range of metal concentrations tested herein, and absent extreme and possibly toxic concentrations of these metals, the accumulation data are congruent with those in a related study of kinky hair syndrome lymphoblasts (34). The conclusions are further supported by results of whole animal studies in blotchy $(30,35)$ and brindled (22) mutants, and are consonant with inferences drawn from work on copper and zinc interrelationships in hepatocytes $(13,36)$ and from the finding of equivalent zinc contents in kinky hair syndrome and normal fibroblasts (2). Taken together with the larger body of data on the Menkes' and mottled mutations, it is reasonable to infer that the defect in both species affects specifically the function of a copper storage or transport system, with the metabolism of zinc and cadmium unaffected.

The differential responses of the fibroblast types to metallothionein inducers support the notion of a mutation limited to derangements in the metabolism of copper. With exposure to either a strong (cadmium) or a weak (zinc) inducer of metallothioneins, radiocopper accumulation was appropriately increased in control cells. However, in mutant cells, there was no change from the characteristically elevated level of isotope accumulation. In reverse experiments, the effects of such inducers on zinc or cadmium accumulation in mutant cells were indistinguishable from the effects on controls.

These results must be considered together with studies of the induction of the synthesis of metallothionein protein, per se, as reported in kinky hair syndrome lymphoblasts (34) and fibroblasts $(2,5)$. Based on the experimental data, it has been concluded that such induction is not impaired in mutant cells $(2,5$, 34). However, a differentially enhanced inducibility of metallothioneins has not been demonstrated, and the aggregate data are entirely consistent with the notion that high metallothionein synthesis in mutant cells is a secondary response to increased intracellular copper concentration (2). Our present observations, viz. normal accumulation and exit of metals other than copper in mutant cells, and a disparate response to metallothionein inducers which is limited to the accumulation of copper, are therefore quite concordant with a construct under which metallothioneins, as a class of proteins, accumulate to high levels secondarily, and not primarily, in mottled and kinky hair syndrome cells. 
The present results provide an important framework for approaching the dissection of the defect in the mottled mutations, and, by analogy, in Menkes' kinky hair syndrome. The distinct responses to metal inducers of metallothionein are herein revealed as a discriminant between normal and mutant cultured cells. The differential response to metallothionein inducers may reflect a primary abnormality in the regulation of a specifically copper-binding thionein or other protein; or may be a secondary consequence of an independent and specific alteration in copper transport. These represent alternative hypotheses which are testable in both cell culture systems and in studies of mutant mouse tissues.

Acknowledgments. We take this opportunity to thank Drs. M. Kaback, M. M. Thaler, and C. Slayman for invaluable advice and suggestions and to express our gratitude to Ms. Beverly Cubbage for her tireless and intelligent editorial efforts in the preparation of the manuscript.

\section{REFERENCES}

1. Beratis NG, Price P, LaBadie GU, Hirschhorn K $1978{ }^{64} \mathrm{Cu}$ metabolism in Menkes' and normal cultured skin fibroblasts. Pediatr Res 12:699-702

2. Bonewitz RF Jr, Howell RR 1981 Synthesis of a metallothionein-like protein in cultured human skin fibroblasts: relation to abnormal copper distribution in Menkes' disease. J Cell Physiol 106:339-348

3. Camakaris J, Mann J, Danks D 1979 Copper metabolism in mottled mouse mutants. Biochem J 180:597-604

4. Camakaris J, Danks DM, Ackland L, Cartwright E, Borger P, Cotton R 1980 Altered copper metabolism in cultured cells from human Menkes' syndrome and mottled mouse mutants. Biochem Genet 18:117-131

5. Chan W-Y, Garnica AD, Rennert OM 1979 Inducibility of metallothionein biosynthesis in cultured normal and Menkes' kinky hair disease fibroblasts: effects of copper and cadmium. Pediatr Res 13:197-203

6. Chan W-Y, Garnica AD, Rennert OM 1978 Cell culture studies of Menkes' kinky hair disease. Clin Chim Acta 88:495-507

7. Cox D, Palmiter R 1983 The metallothionein-I gene maps to mouse chromosome 8: implications for human Menkes' disease. Hum Genet 64:61-64

8. Danks DM, Campbell P, Stevens B, Mayne V, Cartwright E 1972 Menkes' kinky hair syndrome: an inherited defect in copper absorption with widespread effects. Pediatrics 50:188-201

9. Danks D, Campbell P, Walker-Smith J, Stevens B, Gillespie J, Bloomfield J, Turner B 1972 Menkes' kinky-hair syndrome. Lancet 1:1100-1102

10. Danks D, Cartwright E, Stevens B, Townley R 1973 Menkes' kinky hair disease: further definition of the defect in copper transport. Science 179:1140-1142

11. Danks DM 1975 Steely hair, mottled mice and copper metabolism. N Engl J Med 293:1147-1149

12. Dixon WJ, Massey FJ Jr 1969 Introduction to Statistical Analysis. McGrawHill Book Co, Inc, New York

13. Failla M, Cousins $\mathrm{R} 1978$ Zinc uptake by isolated rat liver parenchymal cells. Biochim Biophys Acta 538:435-444
14. Evans GW, Reis BL 1979 Impaired copper homeostatis in neonatal male and adult female brindled mice. J Nutr 108:554-560

15. Goka TJ, Stevenson R, Hefferan P, Howell R 1976 Menkes' disease: a biochemical abnormality in cultured human fibroblasts. Proc Natl Acad Sci USA 73:604-606

16. Goka T, Howell R 1978 Copper metabolism in Menkes' disease. Monogr Hum Genet 10:148-155

17. Hildebrand CE, Crawford B, Enger MD, Griffith BB, Griffith JK, Hanners JL, Longmire JL, Walters RA 1982 Human metallothionein gene mapping and regulation: a somatic cell genetic analysis. J Cell Biol 95:451 A (abstr)

18. Holtzman NA 1976 Menkes' kinky hair syndrome: a genetic disease involving copper. Fed Proc 35:2276-2280

19. Horn N, Mikkelsen M, Heydom K, Darnsgaard E, Tygstrup I 1975 Copper and steely hair. Lancet 1:1236

20. Horn N 1976 Copper incorporation studies on cultured cells for prenatal diagnosis of Menkes' disease. Lancet 1:1156

21. Hunt DM 1974 Primary defect in copper transport underlies mottled mutants in the mouse. Nature 249:852-854

22. Hunt DM, Port AE 1979 Trace element binding in the copper deficient mottled mutants in the mouse. Life Sci 24:1453-1466

23. Kagi JHR, Nordberg M (eds) 1979 Metallothionein. Experientia 34:19-371 (suppl)

24. LaBadie GU, Beratis NG, Price P, Hirschhorn K 1981 Studies of the copperbinding proteins in Menkes' and normal cultured skin fibroblast lysates. J Cell Physiol 106:173-178

25. LaBadie GU, Hirschhorn K, Katz S, Beratis NG 1981 Increased copper metallothionein in Menkes' cultured skin fibroblasts. Pediatr Res 15:257261

26. Lowry OH, Rosebrough NJ, Farr AL, Randall FJ 1951 Protein measurements with the Folin phenol reagent. J Biol Chem 193:265-275

27. Mann JR, Camakaris J, Danks D 1979 Copper metabolism in mottled mouse mutants: distribution of ${ }^{64} \mathrm{Cu}$ in brindled $\left(\mathrm{Mo}^{\mathrm{br}}\right)$ mice. Biochem $\mathrm{J}$ 180:613619

28. Ohno S 1974 Conservation of ancient linkage groups in evolution and some insight into the genetic regulatory mechanism of $\mathrm{X}$-inactivation. Cold Spring Harbor Symp Quant Biol 38:155-164

29. Onishi T, Inubushi H, Tokugawa S, Muramatsu M, Nishikawa K, Suzuki Y, Miyao M 1980 Abnormal copper metabolism in Menkes' cultured fibroblasts. Eur J Pediatr 134:205-210

30. Packman S, O'Toole C, Price D, Thaler M 1983 Cadmium, zinc and copper metabolism in the mottled mouse, an animal model for Menkes' kinky hair syndrome. J Inorg Biochem 19:203-211

31. Packman S, Chin P, O'Toole C 1984 Copper utilization in cultured skin fibroblasts of the mottled mouse, an animal model for Meukes' Kinky hair syndrome. J Inherited Metab Dis, in press, 1984

32. Prins HW, Van den Hamer CJ 1979 Primary biochemical defect in copper metabolism in mice with a recessive $\mathrm{X}$-linked mutation analogous to Menkes' disease in man. $J$ Inorg Biochem 10:19-27

33. Sayed A, Edwards J, Bannerman R 1981 Copper metabolism of cultured fibroblasts from the brindled mouse. Proc Soc Exp Biol Med 166:153-156

34. Riordan J, Jolicoeur-Paquet L 1982 Metallothionein accumulation may account for intracellular copper retention in Menkes' disease. J Biol Chem 257:4639-4645

35. Starcher B, Madaras JA, Fisk D, Perry EF, Hill CH 1978 Abnormal cellular copper metabolism in the blotchy mouse. J Nutr 108:1229-1233

36. Weiner A, Cousins $\mathbf{R} 1980$ Copper accumulation and metabolism in primary monolayer cultures of rat liver parenchymal cells. Biochim Biophys Acta 629:113-125 